\title{
Bovine brucellosis: Seroprevalence and its potential risk factors in smallholder dairy farms in Hawassa Town, Southern Ethiopia
}

\author{
${ }^{1}$ Ataro Abera, ${ }^{2}$ Yosef Deneke, ${ }^{2}$ Tadele Tolosa* \\ ${ }^{1}$ Livestock and Fishery Resource Development Department, Dawuro Zone, Tercha, SNNPRs, \\ Ethiopia, atishabe.dvm@gmail.com,+251910197960 \\ ${ }^{2}$ College of Agriculture and Veterinary Medicine, School of Veterinary Medicine, Jimma Univer- \\ sity, P.O. Box: 307, Jimma, Oromia, Ethiopia, yosefdeneke@yahoo.com, +251917804529 \\ *Corresponding author: tadeletolosa@yahoo.com, +251917804070
}

\begin{abstract}
Bovine brucellosis is an infectious zoonotic disease causing significant economical loses in dairy industry. A cross-sectional study was carried out between October 2017 and July 2018 to estimate the seroprevalence and its associated risk factors in smallholder dairy farms in Hawassa town, Southern Ethiopia. A total of 370 blood samples were collected from cross-bred and local indigenous dairy cattle of above six months of age. One stage cluster sampling technique was used to get the sample of interest. Rose Bengal Plate Test (RBPT) was used as a screening, while serum samples testing positive to RBPT were subjected for complement fixation test (CFT) to confirm. Consequently, RBPT detected 18 of the 370 samples positive for brucellosis exposure. The positive sera when further retested using CFT, 10 out of the 18 RBPT positive sera were confirmed to be positive. The individual animal level prevalence of bovine brucellosis in the study area was $2.7 \%$ and the herd-level prevalence was $25.8 \%$. Higher prevalence was observed in larger herd sizes than the small and medium herds $(p<0.05)$. Likewise, parity number greater than six had more positive animals $(\mathrm{p}<0.05)$ than the corresponding group with lower parity number. Multivariable logistic regression anlysis revealed that herd sizes (OR: 9.13, 95\% CI: 1.87-28.65, p<0.05), number of parity (OR: $11.6: 95 \% \mathrm{CI}$ : 1.54-36.08, p<0.05), absence of separate parturition pen (OR: 7.9, 95\% CI: 1.63 $38.4, \mathrm{p}<0.05)$ and stages of abortion (OR: 7.6, 95\% CI: 1.89-31.36, $\mathrm{P}<0.05)$ were identified as the potential risk factors of bovine brucellosis. The results of this study showed that bovine brucellosis is not highly spread in dairy herds of Hawassa town. Therefore, in order to control spread of bovine brucellosis practicing better management is recommended.
\end{abstract}


Abera et al.,

Keywords: Bovine brucellosis; Dairy farms; Hawassa town; intensive; Risk factor

\section{Introduction}

Ethiopia is a resourceful country with estimated cattle population of 59.5 million (CSA, 2017). The livestock subsector has an enormous contribution to a national economy and livelihoods of many Ethiopians and still promising to rally round the economic development of the country. The subsector contributes about $16.5 \%$ of the national Gross Domestic Product (GDP) and 40\% of the agricultural GDP excluding the values of draught power, manure and transport of people and products (Asresie and Zemedu, 2015). It also contributes $15 \%$ of export earnings and $30 \%$ of agricultural employment (Behnke, 2010).

However, trans-boundary and zoonotic animal diseases such as bovine brucellosis constrain the livestock sector of the country and affect livelihoods via their impact on animal health, animal food production, availability and quality. Bovine brucellosis has a great impact on both animal and human health as well as tremendous socio-economic impact in developing countries where rural income relies largely on livestock breeding and dairy products (Radostits et al., 2007). Brucellosis is considered by Food and Agriculture Organization (FAO), World Health Organization (WHO) and World Organization for Animal health (OIE) as one of the most widespread zoonoses in the world (Schelling et al., 2003). According to OIE, it is the third most important zoonotic disease in the world after rabies and anthrax. The disease affects cattle, swine, sheep, goats, camels and dogs. It may also infect other wild ruminants and marine mammals (Wadood et al., 2009).

The disease is primarily caused by B. abortus and occasionally by B. melitensis where cattle are kept together with infected sheep or goats and characteristically associated with abortion at first gestation ("abortion storm" in naïve heifers) and is mainly caused by biovars (mainly biotype-1) of B. abortus (OIE, 2009; Godfroid et al., 2010). Chronic infection of the mammary glands due to B. suis has also been reported (Lopes et al., 2010). Clinically bovine brucellosis is characterized by impaired fertility specifically with abortion, metritis, orchitis and epididymitis (Radostits et al., 2007). The mode of transmission of the bacteria varies with the epidemiological area, the animal reservoir and the occupational exposed groups (Radostits et al., 2007). A precise diagnosis of 
Brucella spp. infection is important for the control of the disease in animals and consequently in man.

In Ethiopia, the first cases of brucellosis reported in the 1970s. Since the first report of brucellosis the disease has been noted as one of the important livestock diseases in the country (Meyer, 1980; Tariku, 1994; Asfaw et al., 1998; Bekele et al., 2000; Alem and Solomon, 2002; Kebede et al., 2008; Ibrahim et al., 2010; Mekonnen et al., 2010) demonstrating brucellosis is endemic.

Brucellosis is a public health problem with adverse health implications both for animals and human beings as well as economic implications for individuals and communities. Management, animal movement, wide ranges of host, herd size, commingling of different animal species is risk factors for animal brucellosis. The possible risk factors for human brucellosis are feeding behavior, occupational exposure, contact with diseased animals or their products and discharges.

Bovine Brucellosis was studied a decade ago in the areas of Sidama zone of Southern nation nationalities and peoples regional state by Asmare et al. (2007) on intensive and extensive management systems. In these ten years, there is expansion of the town, increasing in population pressure and increasing dairy farms but there was no documented information on status of bovine brucellosis in study area. There are many small and medium dairy farms mushrooming which supply raw milk and milk products for the communities in Hawassa town. The demand for consumption of milk and milk products in the areas also increasing this may leads to zoonotic diseases like brucellosis. So, this study achieved the gap and provided more information on seroprevalence of bovine brucellosis and its potential risk factors that predispose the animals in the study area. The objectives of the current study were to estimate seroprevalence of bovine Brucella antibody circulation in small holder dairy farms of the Hawassa town and to assess the possible risk factors associated with Brucella antibody in the study area.

\section{Materials and methods}

\section{Description of the Study Area}

The study was conducted in Hawassa town, Southern Ethiopia between October 2017 and August 2018. Hawassa is located in the Southern Nation's Nationalities and Peoples Region on the shores of Lake Hawassa in the Great 
Rift Valley and located $275 \mathrm{Km}$ away from Addis Ababa in southern direction. Geographically the City lays at $6^{0} 55^{\prime} 0^{\prime \prime}$ latitude N and $38^{\circ} 25^{\prime} 0^{\prime \prime}$ longitudes E. The annual mean rainfall is from $800-1000 \mathrm{~mm}$ and annual mean temperature is between $20.1-25^{\circ} \mathrm{C}$ (HCAFEDD, 2017). Hawassa town is the economic and cultural hub of the region, having a total area of about $50 \mathrm{~km}^{2}$ being divided into eight sub-cities and 32 Kebeles. It is with estimated human population of 387,087 and the main livestock populations in the town are cattle, goats and sheep and estimated to be 125,284, 39,943 and 42,190, respectively. There are 4,401 equines used for draft service. Dairy production system in Hawassa town is mostly dominated by cross breed animals which the house holds use them for production of milk to sell for the urban communities. (HTLFRDD, 2018).

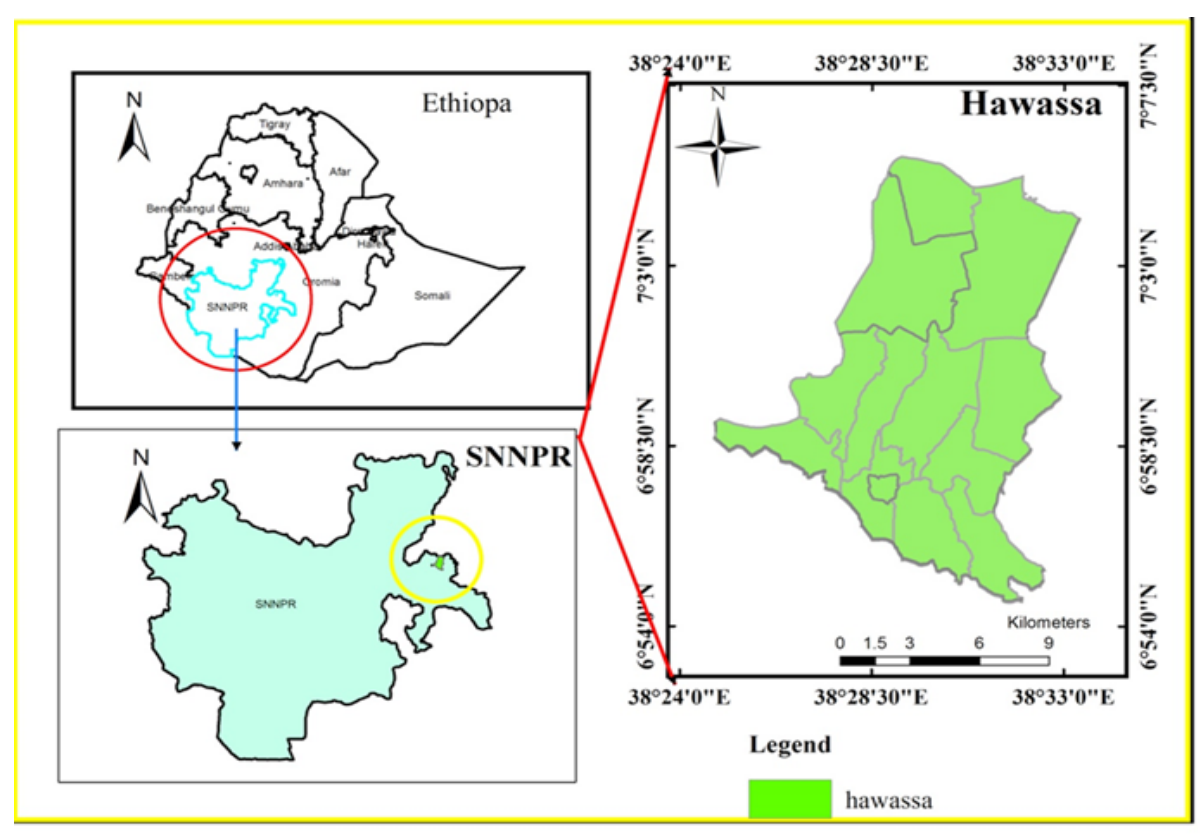

Figure 1. Map of the study area

\section{Study animals and their management}

The study consisted of dairy cattle that were managed under the intensive and semi-intensive production system. According to the criteria of Richard (1993), management systems were classified as semi-intensive husbandry system which includes all animals that both are kept indoor and outdoor while intensive system covers all animals which were kept in closed housing system and 
feed concentrate as well as mixed feed. The cattle under study comprised of the cross breeds and local indigenous Zebu cattle. Animals of both sexes and different age group greater than six months were included in the study.

Dairy cows are kept under tethers feeding and some are natural grazing with supplementation of food industry byproducts. The cross-breed animals mainly the local with Holstein Frisian and Jersey are increasing in number.

\section{Study design}

A cross-sectional study design was carried out on using a pre-tested questionnaire and serological tests.

\section{Sampling method and sample size determination}

The study was included representative major dairy farms in Hawassa town. The sampling frame and sampling strategy were determined as follow:

A list of dairy farms was obtained from Hawassa town livestock and fishery resource offices and dairy owners. Farms were divided into small-scale $(\leq 15$ heads of cattle), medium-scale ( $\geq 16$-29 heads of cattle) and large-scale ( $\geq 30$ heads of cattle) farms depending on number of animals (Asgedom et al., 2016). Those cattle that housed in the same barns were grouped together and considered as one herd (Tolosa et al., 2008; Asgedom et al., 2016). A one stage cluster sampling procedure was used. The clusters were randomly selected and all animals in each cluster were sampled. There are 82 herds in the town: 52 small, 25 medium and 5 large herds. Out of these, 19 small herds (152 head of animals), 10 medium herds (158 head of animals) and 2 large herds (60 head of animals) were sampled in the study area.

The sample size for this study was calculated using $14.14 \%$ of seroprevalence of bovine brucellosis as reported by Desalegn et al. (2011). Therefore, to determine the sample size of dairy cattle in this area, $14.14 \%$ was used as $\mathrm{P}_{\text {exp }}$ and 95\% confidence interval and 5\% required precision (Thrusfield, 2007)

$$
\begin{aligned}
& \mathrm{n}=(\mathrm{Z})^{2} \underline{\mathrm{P}_{\exp }} \frac{\left(1-\mathrm{P}_{\exp }\right)}{\mathrm{d}^{2}} \\
& \text { Where, } \mathrm{n}=\text { required sample size, } \\
& \text { Pexp }=\text { expected prevalence } \\
& \mathrm{d}=\text { desired absolute precision }
\end{aligned}
$$


Accordingly, the sample size was 186 . The sample size was recalculated to get similar accuracy to that of simple random sampling. The intra-cluster correlation coefficient $(\rho)$ of Brucella abortus was calculated from the results of cluster sample survey is 0.09 (Otte and Gumm, 1997). The new sample size formula $\left(n^{\prime}\right)$ was calculated by multiplying $n$ by design effect i.e. $n^{\prime}=n x$ design effect, also Design effect $=1+\rho(m-1)$, where $m$--average number of individuals sampled per cluster $(m=12)$. Therefore, the required sample size for this study was 370 cattle above 6 months of age.

\section{Data collection}

\section{Questionnaire survey}

A total of 31 farm attendants/owners were interviewed using semi-structured questionnaire. A questionnaire survey with open and closed questions was used among the farm owners/ attendants whose farms were tested. The following data was collected on animal attributes: breed, sex, age and reproductive status, parity, stage of abortion (first trimester, second trimester and third trimester), history of abortion and retained fetal membrane and breeding systems. Based on its biological relevance, age was stratified into three categories (0.5- $<3$ years, $\geq 3-6$ years and $>6$ years) (Asgedom et al., 2016). The reproductive status was also categorized (replacement heifers, pregnant cows, lactating cow, dry and bulls). Besides, information on farms such as: herd size was categorized into [small scale ( $\leq 15$ heads of cattle), medium scale ( $\geq 16-29$ heads of cattle) and large scale ( $\geq 30$ heads of cattle)] and other managemental factors were collected. The presence of calving pens ( $\mathrm{No} / \mathrm{Yes})$, waste disposal methods (placenta, aborted material and dead animal) was categorized into (burying, burning and open dump). Hygienic status of the farms was categorized as (clean and not clean) based on manure disposal, drainage and barn ventilation. Farmer's awareness about brucellosis (No/Yes) was assessed.

\section{Blood sample collection and laboratory tests}

\section{Blood sample collection procedure}

Animals were restrained by animal handlers and approximately $10 \mathrm{ml}$ of blood sample was collected from the jugular vein of each animal using vacutainer tubes with 18-20-gauge hypodermic needles. Each sample from each animal 
was labeled by using codes describing the specific animal and herd/farm. The samples were kept under the shade in a slant position for one hour and were centrifuged. If there was no light in the sample collection area, vacutainer tubes with serum were labeled and set tilted on a table overnight at room temperature to allow clotting. Next morning, the clotted blood in the tubes was centrifuged to obtain clear serum. The obtained serum was stored at $-20^{\circ} \mathrm{C}$ until they were tested by both Rose Bengal Plate Test and Complement Fixation Test. Corresponding to each sample, age, sex, breed of every animal, georeference information and other risk factors contributing to the occurrence of bovine brucellosis were collected and registered on a separate case book.

\section{Serological tests}

\section{Rose Bengal plate test (RBPT)}

It was employed as a screening test on the serum samples for the presence of Brucella agglutinins. The protocol of RBPT as recommended by OIE was used as screening test for the presence of Brucella antibody in the sampled sera. This test is generally considered to be as a sensitive test which reports to be 97.9\% sensitive (Dohoo et al., 1986). Before performing test, antigen and sera were brought to room temperature. $30 \mu \mathrm{L}$ of serum was taken on a glass slide by micropipette and the antigen bottle was shaken well to ensure homogenous suspension and then one drop $(30 \mu \mathrm{L})$ of Rose Bengal antigen was added. The antigen and serum were mixed thoroughly with the spreader and then the slide was rotated for $40 \mathrm{~min}$. The result was read immediately after $4 \mathrm{~min}$.

\section{Complement fixation test (CFT)}

All Sera that tested positive to RBPT were further tested using CFT at the National Veterinary Institute (NVI), Debre-Zeit, Ethiopia for confirmation using standard B. abortus antigen S99 (Veterinary Laboratories Agency, New Haw, Addlestone, Surrey KT15 3NB, United Kingdom). Preparation of the reagent was evaluated by titration and performed according to protocols recommended by World Organization for Animal Health (OIE, 2009). Sera with strong reaction, more than $75 \%$ fixation of complement (3+) at a dilution of $1: 5$ or at least with $50 \%$ fixation of complement (2+) at a dilution of $1: 10$ and above was classified as positive and lack of fixation/complete hemolysis was considered as negative. 


\section{Data storage and analysis}

Data obtained from questionnaire survey and laboratory results were recorded and stored in Microsoft ${ }^{\circledR}$ Excel for Windows 2010 and transferred to Statistical Package for the Social Sciences (SPSS) version 20. Data were coded and analyzed using descriptive and analytical statistics as appropriate. The units of analysis were individual cattle and herd. Animal level seroprevalence was computed by the number of positive animals divided by the total number of animals tested and for herd level seroprevalence the number of positive herds was divided to the total number of herds tested. Associations between outcome (brucella sero-positivity) and explanatory variables (risk factors) for all units of analysis were investigated by using binary logistic regression model. The strength of the association between outcome (brucella sero-positivity) and explanatory variables was assessed using the adjusted odds ratios (OR). Multivariable logistic regression procedures were used to model the effects of potential risk factors on outcome variables. The backward elimination procedure was used to eliminate the factors that were not significant at $p<0.05$ in the overall model. Model fit was observed using the Hosmer-Lemeshow test. Subsequently, the predictive ability of the model was validated using the receiver operating characteristic (ROC) curve. In the analysis, a covariate was considered confounder and included in the model if its inclusion altered the OR of the estimated risk by more than 20\% (Dohoo et al., 2009).

\section{Results}

\section{Questionnaire survey}

A total of 31 volunteer farm attendants and owners in the farms were interviewed to assess the awareness about brucellosis. Majority of cattle attendants and owners (54.8\%) have no knowledge about brucellosis (Table 2). The vast majority of the interviewees (93.5\%) were male. Forty-five percent of the respondents in the study area can write and read (Table 1). Fifty five percent of the participants have poor knowledge of the disease. However, the level of awareness was insignificantly lower $(p>0.05)$ in intensive farms. 
Table 1. Socio-demographic Characteristics of Respondents

\begin{tabular}{llcc}
\hline Variables & Categories & Frequency & Percentage (\%) \\
\hline Sex of household & Male & 29 & 93.5 \\
& Female & 2 & 6.5 \\
Age of household & b/n 25-35 & 10 & 32.3 \\
& b/n 36-46 & 12 & 38.7 \\
& $\geq 47$ & 9 & 29 \\
Educational status of & Illiterate & 10 & 32.3 \\
households & write and read & 14 & 45.2 \\
& Primary & 5 & 16.1 \\
& high school & 2 & 6.5 \\
Total & higher education & 0 & 0.0 \\
\hline
\end{tabular}

Almost all of respondents practice intensive husbandry system 28 (90.3\%) and only $3(9.7 \%)$ from the semi-intensive management systems. In intensive farms, artificial insemination (AI) is used for breeding in herds with cross breeds while most herds in semi-intensive farm use bull for breeding. Among intensive farms, $61.3 \%$ of farms were regarded as clean however, $38.7 \%$ of intensive farms and all of the semi-intensive farm management systems had poor hygienic practices including poor waste disposal, drainage and poor barn ventilation observed. Around $20 \%$ of respondents did not dispose waste products (aborted material or afterbirth) properly (Table 2). Generally, the frequency distribution of breed, parity, age group, reproductive status, retained fetal membrane and hygienic practice on farm were summarized in the following table (Table 2 and 3). 
Abera et al.,

Table 2. Respondents' response on management of dairy farm practices

\begin{tabular}{llcc}
\hline Parameters & Categories & Frequency & Percentage (\%) \\
\hline Hygienic practice on & Not clean & 12 & 38.70 \\
farm & Clean & 19 & 61.30 \\
Level of awareness & No & 17 & 54.80 \\
about brucellosis & Yes & 14 & 45.16 \\
Animal introduction & No & 20 & 64.50 \\
& Yes & 11 & 35.50 \\
Separate parturition & No & 14 & 45.16 \\
pen & Yes & 17 & 54.80 \\
Management system & Intensive & 28 & 90.30 \\
& Semi-intensive & 3 & 9.70 \\
Breeding system & Natural mating & 8 & 25.80 \\
& AI & 17 & 54.80 \\
& Both & 6 & 19.40 \\
Disposal of aborted & Burning & 14 & 45.16 \\
fetus/fetal membrane & Burying & 8 & 25.81 \\
& Both & 3 & 9.68 \\
& open dump & 6 & 19.35 \\
Total & & 31 & 100.00 \\
\hline
\end{tabular}

Out of 370 dairy animals, 105 (28.38\%) were local breed whereas 265 (71.62\%) were cross-breeds of indigenous zebu and Holstein Friesian. In addition, the herd characteristics of the studied animals were 107 (28.92\%) milking cows, 21 (5.68\%) pregnant cows, $126(34.05 \%)$ non milking cows, 68 (18.38\%) replacement heifers and $48(12.97 \%)$ bulls. From the total studied animals, there was a history of retained fetal membrane in $29(9.00 \%)$ and $25(7.76 \%)$ were with a history of abortion (Table 3). 
Table 3. Frequency distribution of individual animal variables and percentage

\begin{tabular}{llcc}
\hline Variables & Categories & Frequency & Percentage (\%) \\
\hline Breed & Local & 105 & 28.38 \\
& Cross & 265 & 71.62 \\
Reproductive status & Heifer & 68 & 18.38 \\
& Milking cow & 107 & 28.92 \\
& Non-milking cow & 126 & 34.05 \\
& Bull & 48 & 12.97 \\
History of & Pregnant cow & 21 & 5.68 \\
reproductive & No & 268 & 72.43 \\
problems & Abortion & 25 & 7.76 \\
Sex & RFM & 29 & 9.00 \\
& Male & 48 & 12.97 \\
Body condition score & Poor & 322 & 87.03 \\
& Medium & 160 & 43.24 \\
& Good & 136 & 36.76 \\
Age & $0.5-<3$ & 74 & 20.00 \\
& $\geq 3-6$ & 63 & 17.03 \\
Total & $>6$ & 129 & 34.86 \\
\hline & & 178 & 48.11 \\
& & 370 & 100.00 \\
\hline
\end{tabular}

\section{Overall seroprevalence}

Individual animal level seroprevalence of bovine brucellosis

Out of 370 sera samples collected and screened by RBPT, 18 (4.86\%) (95\% CI: $2.67 \%-7.10 \%$ ) were seropositive for brucella antibody. Among 18 brucella positive reactors, 10 (2.70\%) (95\% CI: $1.05 \%$ - 4.36\%) of them were confirmed to be seropositive by CFT test. Animals with the age between $0.5-<3$ years, replacement heifers, animals which abort at the stage of first trimester and semiintensive management system tested were negative in both RBPT and CFT. 
Abera et al.

Table 4. Animal level risk factors and brucella seropositivity in Hawassa town

\begin{tabular}{|c|c|c|c|c|c|c|}
\hline Risk factors & Categories & $\begin{array}{l}\text { No of } \\
\text { tested }\end{array}$ & $\begin{array}{l}\text { No of } \\
\text { positive }\end{array}$ & $\begin{array}{l}\text { Prevalence } \\
\text { (\%) }\end{array}$ & $95 \%$ CI & $P$-value \\
\hline \multirow{3}{*}{$\begin{array}{l}\text { Body condition } \\
\text { score }\end{array}$} & Poor & 160 & 6 & 3.75 & $0.81-6.69$ & \multirow[t]{3}{*}{0.38} \\
\hline & Medium & 136 & 2 & 1.47 & $0.55-3.49$ & \\
\hline & Good & 74 & 2 & 2.70 & $0.99-6.40$ & \\
\hline \multirow[t]{2}{*}{ Sex } & Male & 48 & 1 & 2.10 & $0.15-16.15$ & \multirow[t]{2}{*}{0.17} \\
\hline & Female & 322 & 9 & 2.80 & $0.30-0.92$ & \\
\hline \multirow[t]{4}{*}{ Parity } & No & 75 & 1 & 1.33 & $1.26-3.93$ & \multirow[t]{4}{*}{0.04} \\
\hline & $1-3$ & 129 & 1 & 0.78 & $0.74-2.29$ & \\
\hline & $4-6$ & 67 & 2 & 2.99 & $1.09-7.06$ & \\
\hline & $>6$ & 51 & 5 & 9.38 & $1.64-17.97$ & \\
\hline \multirow[t]{4}{*}{ Stage of abortion } & Never & 75 & 4 & 5.33 & $0.53-3.4$ & \multirow[t]{4}{*}{0.03} \\
\hline & 1st trimester & 129 & 0 & 0.00 & $0.00-2.89$ & \\
\hline & 2nd trimester & 67 & 3 & 4.48 & $0.47-9.43$ & \\
\hline & 3rd trimester & 51 & 3 & 5.88 & $0.58-12.34$ & \\
\hline \multirow[t]{2}{*}{ Breed } & Local & 105 & 4 & 3.8 & $0.15-7.47$ & \multirow[t]{2}{*}{0.92} \\
\hline & Cross & 265 & 6 & 2.26 & $0.47-4.1$ & \\
\hline \multirow{5}{*}{$\begin{array}{l}\text { Reproductive } \\
\text { status }\end{array}$} & Heifer & 68 & 0 & 0.00 & $0.00-0.06$ & \multirow[t]{5}{*}{0.48} \\
\hline & Milking cow & 107 & 4 & 3.74 & $0.14-7.33$ & \\
\hline & $\begin{array}{l}\text { Non-milking } \\
\text { cow }\end{array}$ & 126 & 4 & 3.17 & $0.11-6.24$ & \\
\hline & Bull & 48 & 1 & 2.1 & $1.96-6.12$ & \\
\hline & Pregnant cow & 21 & 1 & 4.76 & $4.35-13.87$ & \\
\hline
\end{tabular}


Table 5. Herd level risk factors and brucella seropositivity in Hawassa town

\begin{tabular}{|c|c|c|c|c|c|c|}
\hline Risk factors & Categories & $\begin{array}{l}\text { No of } \\
\text { tested }\end{array}$ & $\begin{array}{l}\text { No of } \\
\text { positive }\end{array}$ & $\begin{array}{l}\text { Prevalence } \\
\text { (\%) }\end{array}$ & $95 \%$ CI & P-value \\
\hline \multirow[t]{3}{*}{ Herd size } & $\leq 15$ & 19 & 1 & 5.26 & $4.78-15.30$ & 0.04 \\
\hline & $16-29$ & 10 & 4 & 40.00 & $9.64-70.36$ & \\
\hline & $\geq 30$ & 2 & 2 & 100.00 & $100-100$ & \\
\hline \multirow{2}{*}{$\begin{array}{l}\text { Hygienic } \\
\text { practice on } \\
\text { farm }\end{array}$} & Not clean & 12 & 2 & 16.67 & $4.42-37.75$ & 0.26 \\
\hline & Clean & 19 & 6 & 31.6 & $10.68-52.5$ & \\
\hline \multirow{2}{*}{$\begin{array}{l}\text { Animal } \\
\text { introduction }\end{array}$} & No & 20 & 6 & 30.0 & $9.92-50.1$ & 0.83 \\
\hline & Yes & 11 & 2 & 18.18 & $4.61-40.97$ & \\
\hline \multirow{2}{*}{$\begin{array}{l}\text { Separate } \\
\text { parturition pen }\end{array}$} & No & 14 & 6 & 42.86 & $16.93-68.8$ & 0.04 \\
\hline & Yes & 17 & 2 & 11.76 & $3.6-27.1$ & \\
\hline \multirow{2}{*}{$\begin{array}{l}\text { Management } \\
\text { system }\end{array}$} & Intensive & 28 & 8 & 28.57 & $11.84-45.3$ & 0.82 \\
\hline & $\begin{array}{l}\text { Semi- } \\
\text { intensive }\end{array}$ & 3 & 0 & 0.00 & $0.00-0.00$ & \\
\hline \multirow[t]{3}{*}{$\begin{array}{l}\text { Breeding } \\
\text { system }\end{array}$} & $\begin{array}{l}\text { Natural } \\
\text { mating }\end{array}$ & 8 & 4 & 50.0 & $15.35-84.7$ & 0.54 \\
\hline & $\mathrm{AI}$ & 17 & 3 & 17.7 & $0.47-35.77$ & \\
\hline & Both & 6 & 1 & 16.67 & $13.15-46.5$ & \\
\hline
\end{tabular}

Herd-level seroprevalence of bovine brucellosis

Out of 31 herds included in the study, 8 herds were sero-positive with at least one seropositive animal in the herd (8/31) (25.8\%) (95\% CI: 10.4\%-41.2\%). The range of herd level prevalence was within $5.56 \%$ up to $8.33 \%$ which at least one seropositive animal was observed based on CFT. In this study herds with larger herd size (greater 30 animals) has significantly higher prevalence than herds with small herd size $(\mathrm{p}<0.05)$. The value of OR indicated that herds in the herd size of 16-29 animals were about 9.13 times more likely to be seropositive than herds in the $\leq 15$ heads of animals. However, management systems $(p>0.05)$, Body condition score $(p>0.05$ Sex $(p>0.05)$ and Breed $(p>0.05)$ were not associated with seropositivity of brucellosis (Table 4 and 5 ). 
Abera et al.,

Table 6. Univariable logistic regression analysis of factors associated with Brucella seropositivity

\begin{tabular}{|c|c|c|c|c|c|}
\hline Variables & Categories & $\begin{array}{l}\text { No of } \\
\text { tested } \\
\text { animals }\end{array}$ & $\begin{array}{l}\text { No of CFT } \\
\text { positive } \\
(\%)\end{array}$ & OR (95\% CI) & P-value \\
\hline \multirow[t]{2}{*}{ Sex } & M (Ref) & 48 & $1(2.1)$ & & \\
\hline & $\mathrm{F}$ & 322 & $9(2.8)$ & $4.1(0.6-8.26)$ & 0.17 \\
\hline \multirow[t]{3}{*}{ Herd size } & $\leq 15$ (Ref) & 152 & $1(0.66)$ & & \\
\hline & $\geq 16-29$ & 158 & $5(3.16)$ & $2.56(0.01-4.8)$ & 0.05 \\
\hline & $\geq 30$ & 60 & $4(6.67)$ & $3.4(0.2-4.08)$ & 0.04 \\
\hline \multirow[t]{4}{*}{ Parity } & No (Ref) & 75 & $1(1.33)$ & & \\
\hline & $1-3$ & 129 & $1(0.78)$ & $0.87(0.01-2.96)$ & 0.26 \\
\hline & $4-6$ & 67 & $2(2.99)$ & $4.6(1.32-6.52)$ & 0.09 \\
\hline & $>6$ & 51 & $6(9.38)$ & $5.42(2.04-7.62)$ & 0.04 \\
\hline \multirow[t]{4}{*}{ Stage of abortion } & Never & 75 & $4(5.33)$ & & \\
\hline & 1st trimester & 129 & $0(0.00)$ & $0.8(0.03-0.98)$ & 0.82 \\
\hline & 2nd trimester & 67 & $3(4.48)$ & $7.4(0.49-42.8)$ & 0.03 \\
\hline & 3rd trimester & 51 & $3(5.9)$ & $3.54(0.98-7.23)$ & 0.05 \\
\hline \multirow[t]{2}{*}{ Breed } & Local & 105 & $4(3.8)$ & $0.122(0.01-1.67)$ & 0.92 \\
\hline & Cross (Ref) & 265 & $6(2.26)$ & & \\
\hline \multirow{2}{*}{$\begin{array}{l}\text { Management } \\
\text { system }\end{array}$} & Intensive & 334 & $10(2.99)$ & $0.57(0.06-0.87)$ & 0.82 \\
\hline & $\begin{array}{l}\text { Semi- } \\
\text { intensive } \\
\text { (Ref) }\end{array}$ & 36 & $0(0.00)$ & & \\
\hline \multirow{2}{*}{$\begin{array}{l}\text { Observed } \\
\text { abortion/RFM }\end{array}$} & No & 268 & $2(0.75)$ & $0.4(0.02-14.9)$ & 0.29 \\
\hline & Yes (Ref) & 54 & $7(12.96)$ & & \\
\hline \multirow{2}{*}{$\begin{array}{l}\text { Separate } \\
\text { parturition pen }\end{array}$} & No & 167 & $6(3.6)$ & $4.72(0.98-15.24)$ & 0.04 \\
\hline & Yes (Ref) & 203 & $4(1.97)$ & & \\
\hline
\end{tabular}

OR: Odd ratio; CI: Confidence interval; Ref: Reference

\section{Potential risk factors}

Variables with a $\mathrm{p}<0.25$ in the univariable analysis were included in the final multivariable logistic model. Two variables, age and parity that showed collinearity with each other, so age was removed from the model and parity stayed in the model. The rest variables; parity, herd size, separate parturition pen, stage of abortion was offered to the model. Further selection of variables in the final model was based on stepwise backward elimination procedure. A Hosmer-Lemeshow goodness-of-fit value $(p=0.63)$, indicated that the model 
was fit the data. The area under the ROC curve was 0.54 , indicating that the model had good predictive ability.

The sero-prevalence was significantly higher in the greater than six parity numbers of animals (9.38\%) than the parity numbers between 4-6 ones $(2.99 \%)$, consequently the seroprevalence increases as the parity of the animals increase. This study revealed that there is association between parity and seropositivity of bovine brucellosis with $(p<0.05)$.

Higher prevalence was observed in larger herd size (6.67\%); old animals were affected more than young animal and no brucella reactors were observed in young animals in this finding. Seroprevalence of $12.0 \%$ was observed in animals with previous history of abortion.

The final multivariable logistic regression model showed that parity, absence of separate parturition pen, herd size and stage of abortion were independently associated with seroprevalence of bovine brucellosis. The multivariable logistic regression model revealed that herd size (OR: 9.13; 95\% CI: 1.87-28.65, $\mathrm{p}<0.05$ ), stage of abortion (OR: 7.6; 95\% CI: 1.89-31.36, $\mathrm{p}<0.05$ ), separate parturition pen (OR: 7.9; 95\% CI: 1.63-38.4, p<0.05) and parity (OR: 11.6; 95\% CI: $1.54-36.08, \mathrm{p}<0.05)$ were potential risk factors for cattle seropositivity to circulating brucella antibodies (Table 7).

Table 7. Multivariable logistic regression analysis of potential risk factors with Brucella seropositivity

\begin{tabular}{|c|c|c|c|c|c|}
\hline Variables & Categories & $\begin{array}{l}\text { No of tested } \\
\text { animals }\end{array}$ & $\begin{array}{l}\text { No of CFT } \\
\text { positive (\%) }\end{array}$ & OR $(95 \% \mathrm{CI})$ & P-value \\
\hline \multirow[t]{3}{*}{ Herd size } & $\leq 15$ (Ref) & 152 & $1(0.66)$ & & \\
\hline & $16-29$ & 158 & $5(3.1)$ & $2.45(1.07-3.98)$ & 0.034 \\
\hline & $\geq 30$ & 60 & $4(6.67)$ & $9.13(1.87-28.65)$ & 0.001 \\
\hline \multirow{2}{*}{$\begin{array}{l}\text { Separate } \\
\text { parturition pen }\end{array}$} & No & 167 & $6(3.6)$ & $7.9(1.63-38.4)$ & 0.021 \\
\hline & Yes (Ref) & 203 & $4(1.97)$ & & \\
\hline \multirow[t]{4}{*}{ Stage of abortion } & Never (Ref) & 75 & $4(5.33)$ & & \\
\hline & 1st trimester & 129 & $0(0.00)$ & $1.8(1.2-2.14)$ & 0.043 \\
\hline & 2nd trimester & 67 & $3(4.48)$ & $5.5(1.07-18.2)$ & 0.004 \\
\hline & 3rd trimester & 51 & $3(5.9)$ & 7.6(1.89-31.36) & 0.001 \\
\hline \multirow[t]{4}{*}{ Parity } & No (Ref) & 75 & 1(1.33) & & \\
\hline & $1-3$ & 129 & $1(0.78)$ & $2.45(0.35-4.03)$ & 0.128 \\
\hline & $4-6$ & 67 & $2(2.99)$ & $6.12(1.14-11.08)$ & 0.041 \\
\hline & $>6$ (Ref) & 51 & $6(9.38)$ & $11.6(1.54-36.08)$ & 0.001 \\
\hline
\end{tabular}

Ethiop. Vet. J., 2019, 23 (2), 41-63 


\section{Discussion}

Awareness about brucellosis among farmers is crucial in controlling disease transmission. In this study, farm attendants/herd owners were interviewed to assess their awareness levels about brucellosis using semi-structured questionnaire. All farmers interviewed had no similar awareness about brucellosis and farmers which were aware about brucellosis were significantly lower in both farming systems. It also observed that poor hygienic practices and uncontrolled animal movements were practiced in semi-intensive husbandry systems. These could pose high risks of transmitting the disease within and in between the herds. This is in agreement with previous studies in intensive farming in Ethiopia by Tesfaye et al. (2011); Asgedom et al. (2016); Elemo and Geresu. (2018) and Waktole et al. (2018).

This low level of educational status may lead to reduced production of dairy farms because of low use of dairy innovations such as cultivation of improved forages, breeding techniques and use of modern dairy farming in the study area. This study revealed that the occurrence of abortion and retained fetal membrane was due to lack of knowledge on breeding methods and disease transmission, shortage of feed and lack of awareness on isolation of aborted animal from healthy animals could possibly be associated with the high prevalence rate of reproductive problems.

Similar prevalence to the current study of bovine brucellosis based on RBT and CFT has been reported from the highland areas of Ethiopia among cattle in intensive production systems (Asmare et al., 2004; Kebede et al., 2008; Jergefa et al., 2009). However; in certain parts of the Ethiopia some authors observed lower prevalence in indigenous cattle under intensive production systems by using the same diagnostic tests (Tolosa et al., 2010; Alemu et al., 2014; Geresu et al., 2015; Asgedom et al., 2016). This variation could be due to differences in cattle management systems, husbandry practices.

The current finding was consistent with earlier findings of Asmare (2004) who reported $2.5 \%$ prevalence in Sidama zone dairy farms by using the same tests and management practices; Waktole et al. (2018) who reported a prevalence of $3 \%$ in selected dairy farms of Bishoftu town, Oromia region; Asmare et al. (2007) documented a seroprevalence of $2.46 \%$ in sidama zone and Tesfaye et al. (2017) who observed 2.08\% seroprevalence in and around Kombolcha, Amhara regional state. 
However, in Ethiopia a lower seroprevalence which contradict the current study were documented in previous findings of Bashitu et al. (2015) who observed a seroprevalence of $0.2 \%$ which conducted on 415 animals by using RBPT and CFT tests in Debrebirhan and Ambo towns and Sarba et al. (2016) who reported an overall seroprevalence of $0.49 \%$ on 816 animals using the same tests in selected towns of West Shewa, Ethiopia; Geresu et al. (2016) who observed $1.4 \%$ seropositivity of brucella on 570 animals using RBPT, CFT CT and i-ELISA tests in dairy cows in Asella and Bishoftu towns, Oromia regional state, Ethiopia and Tesfaye et al. (2011) who reported 1.5\% prevalence in Addis Abeba dairy farms by using the same tests.

In the contrary, so far higher seroprevalence findings are reported by Elemo and Geresu (2018) who observed prevalence of $4.95 \%$ on 768 animals using RBPT and CFT tests in smallholder farms of Agarfa and Berbere districts of Bale Zone, South Eastern Ethiopia; Kebede et al. (2008) reported an overall seroprevalence of $11.0 \%$ on 1136 cattle using RBPT and CFT tests in WuchaleJida district; Alehegn et al. (2016) who reported 4.9\% seroprevalence in and around Gondar Town, North West Gondar; Desalegn et al. (2011) who observed $14.14 \%$ of prevalence using the same tests in Assella Government Dairy Farm of Oromia Regional State, Ethiopia and Hailemelekot et al. (2007) who observed $4.6 \%$ of prevalence using the same tests in selected sites of Ethiopia.

The difference in seroprevalence might be due to the difference in management systems, age of the animals, sample sizes, parity of the animals, herd sizes and sex among dairy farms. It has been reported that susceptibility of cattle to $B$. abortus infection is influenced by age of an individual animal. Thus, sexually matured and pregnant cattle are more susceptible to infection with Brucella organisms than sexually immature animals of either sex. On the other hand, younger animals tend to be more resistant to infection and frequently clear infections, although latent infection may occur. This may be due to the fact that sex hormones and erythritol, which stimulates the growth and multiplication of Brucella organisms, tend to increase in concentration with age and sexual maturity (Radostits et al., 2007)

This study also estimated that there is association between parity and seropositivity of bovine brucellosis and hence, parity was one of the potential risk factors in the study area. This is probably due to increased contact with fetal materials and vaginal discharge from infected cows there by increasing the chance of being infected by brucella species. This finding was in agreement 
with the findings of other authors (Desalegn et al., 2011; Elemo and Geresu, 2018).

Even though age was not significantly associated with brucella seropositivity, a seroprevalence of 3.37 was found among age group of $>6$ years whereas no brucella seropositivity was observed in in the younger age group (6 months up to less than three years) of dairy cattle in the study area. Several earlier reports have indicated that the higher seroprevalence of brucellosis in adult age group of cattle which in contour with the findings of Magona et al. (2009) similar to the findings of this study. This report was in line with literatures which supports younger animals tend to be more resistant to infection and frequently clear infections. Sexually mature animals are more susceptible to Brucella infection than sexually immature animals, which are due to the fact that sex hormones and erythritol, which stimulate the growth and multiplication of Brucella organism, tend to increase in concentration with age and sexual maturity (Walker, 1999; Radostits et al., 2007).

There was statistically significant association between $(p<0.05)$ stage of abortion and seropositivity of brucella in the present study. This could be explained by the prevalence of higher seroprevalence in cows in the last trimester may due to the preferential localization of brucella in the uterus in which allantoic fluid factors such as erythritol could stimulate the growth of brucella and elevate in the placenta and fetal fluid from about the fifth months of gestation (Coetzer and Tustin, 2004; Radostits et al., 2007).

In the present study, statistically significant variation has been observed in seroprevalence of brucellosis between different herd sizes; larger herd sizes were nine times more likely to be seropositive. Herd size has previously been reported as an important determinant for transmission of Brucella organism between susceptible and infected animals (Omer et al., 2000) and thus; larger herds were more likely to have at least one positive animal than smaller herds (Al-Majali et al., 2008). In larger herd sizes, the disease spreads by several modes of transfer, especially through contact with infected discharges from dam and its fetus (Radostits et al., 2007). Thus, brucellosis should never be viewed as the disease of individual animals, but should be considered in the context of herd and also the animal population in the region. However, in contrary to this Kebede et al. (2008), who reported that the risk of seropositivity was independent of herd size in Wuchale Jida district of East Wollega zone of Ethiopia. The observed variation of the reports among different region of 
Ethiopia and other countries could be attributed to various factors including agro-ecology, management system. In the current finding the absence of separate parturition pen in the study area was significantly associated with brucella seropositivity. This is due to hygienic problems in dairy farms in which the sanitary systems of farm are not clean. This predisposes the animals to the disease.

In epidemiological studies, the use of two tests applied serially is recommended to maximize the accuracy of test results. A combination of rose Bengal and complement fixation tests is the most widely used serial testing scheme. Rose Bengal test is highly sensitive test and could easily apply in field conditions whereas, complement fixation test is highly specific usually used as a confirmatory test method (Samui et al., 2007). The combination of these tests in this study could therefore maximize the accuracy of the findings. The false positive results in the RBT could be due to cross reactions with other bacteria such as Yersinia enterocolitica, E. coli, Salmonella spp. and Pastuerella spp.

\section{Conclusion}

In the current study, the seroprevalence recorded revealed that brucella antibody circulation is an established disease in dairy farms of Hawassa town. The current finding revealed that large herd sizes, absence of separate parturition pen, animals with the highest number of parity and animals which aborted at last trimester were identified as potential risk factors of brucella seropositivity. Even though age was not significantly associated with brucellosis, adult animals were highly predisposed than young animals and almost all of the positive reactors were female animals. From questionnaire survey, poor hygienic practices like improper disposal of aborted fetuses and fetal membranes were identified as potential risk factors which could create favorable condition for the entry and establishment of bovine brucellosis in the dairy farms. In conclusion, the prevailing Brucella seropositivity in the dairy farms indicates the disease has a major impact on human health, besides causing significant economic losses in dairy industry. Hence, using calving pens, improving hygiene, and awareness creation to farm attendants/owners are recommended to control further spread of the disease. 


\section{Acknowledgements}

Authors would like to acknowledge Jimma University, College of Agriculture and Veterinary Medicine academic and support staff members, for their positive cooperation during the study.

\section{References}

Alehegn E., Tesfaye S. and Chane M., 2016. Seroprevalence of Bovine Brucellosis and its Risk Factors in Cattle in and around Gondar Town, North West Gondar, Ethiopia. J Dairy Vet. Anim. Res., 4 (4), 166.

Alem W. and Solomon G., 2002. A retrospective sero-epidemiology study of Bovine Brucellosis in different Production Systems in Ethiopia. In Proceeding of $16^{\text {th }}$ Annual Conference, Addis Ababa, Ethiopia. Pp. 53-57.

Alemu F., Admasu P., Feyera T. and Niguse A., 2014. Seroprevalence of Bovine Brucellosis in Eastern Showa, Ethiopia. Acad. J. Anim. Dis., 3 (3), 27-32.

Al-Majali, A. M., Abdelsalam, Q. T., Mustafa, M. A. and Mohammed, M. A., 2008. Seroprevalence and risk factors for bovine brucellosis in Jordan. J. Vet. Sci., 10, 61-65.

Asfaw, Y., B. Molla, B., Zessin H. K. and Tegene A., 1998. The Epidemiology of Bovine Brucellosis in Intra and Peri-urban Dairy Production Systems in and around Addis Ababa. Bull. Anim. Hlth. Prod. Afr., 46, 217-224

Asgedom, H., Damena, D., and Duguma, R., 2016. Seroprevalence of bovine brucellosis and associated risk factors in and around Alage district, Ethiopia. Springer Plus; 5: 851.

Asmare K. 2004. Epidemiology of Brucellosis in Cattle and its Sero Prevalence in Animal Health Professionals in Sidama Zone, Southern Ethiopia. MSc Thesis, Addis Ababa University, College of Veterianry Medicine. Debre Zeit, Ethiopia.

Asmare, K., Shiv P, Yilkal A, Esayas, G, Gelagaye A, Aschalew Z., 2007. Seroprevalence of brucellosis in cattle and high-risk professionals in Sidama Zone, Southern Ethiopia. Ethiop. Vet. J., 11, 69-84.

Asresie, A., and Zemedu, L., 2015. Contribution of livestock sector in Ethiopian economy: A Review. Advanced Life Sci. Tech., 29, 79-90.

Bashitu, L., Afera B, Tuli G, Aklilu F., 2015. Sero-prevalence Study of Bovine Brucellosis and its Associated Risk Factors in Debrebirhan and Ambo Towns. J. Dairy Ve.t Anim. Res., 3, 131.

Behnke, R., 2010. The contribution of livestock to the economies of IGAD Member States: Study findings, application of the methodology in Ethiopia and recommen- 
dations for further Work. IGAD LPI Working Paper 02-10. Great Wolford, UK: Odessa Centre, IGAD Livestock Policy Initiative.

Bekele, A., Molla, B., Asfaw, Y., Yigezu, L., 2000. Bovine brucellosis in ranches and farms in Southeastern Ethiopia. Bull. Anim. Hlth. Prod., Afr., 48, 13-17.

Coetzer, J.W., and Tustin, R.C., 2004. Infectious diseases of livestock. $3^{\text {rd }}$ ed. South Africa, Oxford University press, Pp: 34-39.

CSA, 2017. Federal Democratic Republic of Ethiopia Central Statistical Agency. Agricultural sample survey 2016/17. Report on livestock and livestock characteristics. Statistical Bulletin, Pp. 1-188.

Desalegn, F., Berhe, T. and Gangwar S. K.., 2011. Seroprevalence Study of Bovine Brucellosis in Assella Government Dairy Farm of Oromia Regional State, Ethiopia. I.J.S.N., 2(3), 692-697.

Dohoo, I., Wright, P., Ruckerbauer, G., Samagh, B., Robertson, F., et al., 1986. A comparison of five serological tests for bovine brucellosis. Can. J. Vet. Res., 50, 485493.

Dohoo, I., Martin, W., Stryhn, H., 2009. Veterinary epidemiologic research, $2^{\text {nd }}$ ed. AVC, Charlottetown, Prince Edward Island, Pp. 239-249.

Elemo, K. K., and Geresu. M. A., 2018. Bovine brucellosis: Seroprevalence and its associated risk factors in cattle from smallholder farms in Agarfa and Berbere districts of Bale Zone, South Eastern Ethiopia. J. Anim. Plant Sci., 28 (2).

Geresu, M. A., Ameni, G., Kassa, T., Tuli, G., Arenas, A., and Kassa, G.M., 2016. Seropositivity and risk factors for brucella in dairy cows in Asella and Bishoftu towns, Oromia Regional State, Ethiopia. Afr. J. Microbiol. Res., 10 (7), 203-213.

Godfroid, J., Nielsen, K. and Saegerman, C., 2010. Diagnosis of brucellosis in livestock and wildlife. Croat. Med. J., 51, 296-305.

Hailemelekot M, Kassa T, Tefera M, Belihu K, Asfaw Y, Ali A., 2007. Seroprevalence of brucellosis in cattle and occupationally related humans in selected sites of Ethiopia. Ethiop. Vet. J., 11, 85-100.

HCAFEDD, 2017. Hawassa City Administration Finance and Economic Development Department. Socio-economic and Geo-spatial data analysis and dissemination core work process. Socio-economic profile. (unpublished).

HTLFRDD, 2018. Hawassa town livestock and fishery resource development department. (unpublished).

Ibrahim, N., Belihu, K., Lobago, F. and Bekana, M., 2010. Sero-prevalence of bovine brucellosis and its risk factors in Jimma zone of Oromia Region, South-western Ethiopia. Trop. Anim. Health. Prod., 42, 34-40. 
Jergefa, T., Kelay, B., Bekana, M., Teshale, S., Gustafson H. and Kindahl, H., 2009.Epidemiological study of bovine brucellosis in three agro-ecological areas of central Oromiya, Ethiopia. Rev. Sci. Tech., 28 (3), 933-943.

Kebede, T., Ejeta, G. and Ameni, G., 2008. Seroprevalence of bovine brucellosis in smallholder farms in central Ethiopia (Wuchale-Jida district). Revue Méd Vét., 159, 3-9.

Lopes, L. B., Nicolino, R. and Haddad, J. P. A., 2010. Brucellosis-risk factors and prevalence: A review. Open. Vet. Sci. J., 4, 72-84.

Magona, W. J., Walubengo, J., Galiwango, T. and Etoori, A., 2009. Seroprevalence and potential risk factors of bovine brucellosis in zero grazing and pastoral dairy systems in Uganda. Trop. Anim. Hlth. Prod., 41:1765-1771.

Mekonnen, H., Kalayou, S., and Kyule, M., 2010. Serological survey of bovine brucellosis in Barka and Arado breeds (Bos indicus) of western Tigray, Ethiopia. Prev. Vet. Med., 94 (1-2), 28-35.

Meyer, M. E. (1980). Report on Veterinary Activities, Institute of Agricultural Organization Research, Ethiopia. Food and Agriculture organization of the United Nations, Rome, Italy. Pp: 24.

Office International des Epizooties (OIE), 2009. Bovine brucellosis in terrestrial manual; http://www.oie.int/.

Omer, M. K., Skejerve, E., Holstad, G., Woldehiwet, Z., and Macmillan, A. P., 2000. Prevalence to Brucella species in cattle, sheep, goat, horses and camels in the state of Eritrea; influence of husbandry system. Epidemiol. Infect., 125, 447-453.

Otte, M. G., and Gumm, I. D., 1997. Intra-cluster correlation coefficients of 20 infectious calculated from the results of cluster sample surveys. Prev. Vet. Med., 31, 147-150.

Radostits, O. M., Gay, C. C., Hinchcliff, K.W., Constable, P. D., 2007. Veterinary Medicine. A text book of Diseases of Cattle, Sheep, Pigs, Goats and Horses, $10^{\text {th }}$ Ed. W. B.,Saunders, London, Pp. 963-985.

Richard, W., 1993. Dairying. Tropical Agriculturalist, $1^{\text {st }}$ Ed. Macmillan Press, London. Pp. 43-48.

Samui, K. L, Oloya, J, Munyeme, M, Skjerve, E., 2007. Risk factors for brucellosis in indigenous cattle reared in livestock-wildlife interface areas of Zambia. Prev. Vet. Med., 80, 306-317.

Sarba, E. J., Getaneh A. M., Borena B. M., Ambecha H. A., Berecha M. S., Eteya W. T., Tola G. K. 2016. Seroprevalence and associated risk factors of brucellosis in dairy cattle in selected towns of West Shewa, Ethiopia. Bull. Anim. Hlth. Prod. Afr., 64, 387-395. 
Schelling, E., Diguimbaye, C., Daoud, S., et al., 2003. Brucellosis and Q fever seroprevalence of nomadic pastoralists and their livestock in Chad. Prev. Vet. Med., 61, 279-293.

Tariku, S., 1994. The impact of brucellosis on productivity in improved dairy herd of Chaffa State Farm, Ethiopia. Berlin, Frei universitate, Fachburg Veterinaemedizin.

Tesfaye, G., Tsegaye, W., Chanie, M. and Abinet, F., 2011: Seroprevalence and associated risk factors of bovine brucellosis in Addis Ababa dairy farms. Trop. Anim. Hlth. Prod., 43, 1001-1005.

Tesfaye, G., Wondimu, A., Asebe, G., Regasa, F., Mamo, G., 2017. Sero-prevalence of Bovine Brucellosis in and Around Kombolcha, Amhara Regional State, Ethiopia. Mycobacter. Di., 7(2), 242

Thrusfield, M. 2007. Sample size determination. In: Veterinary Epidemiology. 3rd ed., UK: Blackwell Science Ltd, Pp.185-189.

Tolosa, T., Regassa, F., and Belihu, K., 2008. Seroprevalence study of bovine brucellosis in extensive management system in selected sites of Jimma zone, western Ethiopia. Bull. Anim. Hlth. Prod. Afr., 56, 25-37.

Tolosa, T., Bezabih, D., and Regassa, F., 2010. Study on seroprevalence of bovine brucellosis, abortion and associated risk factor. Bull. Anim. Hlth. Prod. Afr., 58, 236-247.

Wadood, F., Ahmad, M., Khan, A., Gul, S. T., and Rehman, N., 2009. Seroprevalence of brucellosis in horses in and around Faisalabad. Pak. Vet. J., 29, 196-198.

Waktole, H., Geneti, E., Ahmed, W.A., Mammo, G., and Abunna, F., 2018. Seroprevalence and risk factors of bovine brucellosis in selected dairy farms in Bishoftu, Oromia, Ethiopia. Intl. J. Microbiol. Res., 9 (2), 45-53.

Walker, R. L., 1999. Brucella. In: Hirsh D. C, Zee Y. C (eds.) Veterinary Microbiology Malden, USA, Blackwell Science, Pp. 196-203. 